\title{
جماليات النقد الثقافي في المكون المسرحي
}

م.د. منتهى طارق حسين المهناوي

جامعة واسط. كلية القنون الجميلة

دفع انفتاح الأدب في القرن العشرين على العلوم الإنسانية كافة، و الفنون خاصة إلى ولادة اشكال جديدة من التعبير اللفظي، والبصري، التي حققت انتشار ا واسعا بفضل وسائل الاتصـال

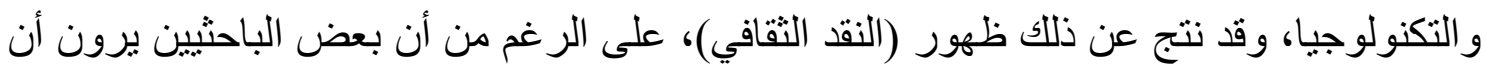

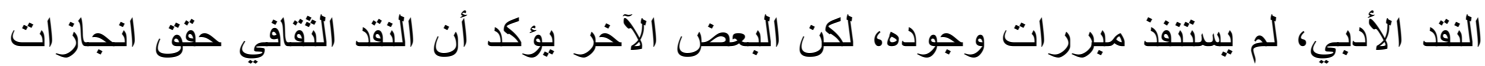

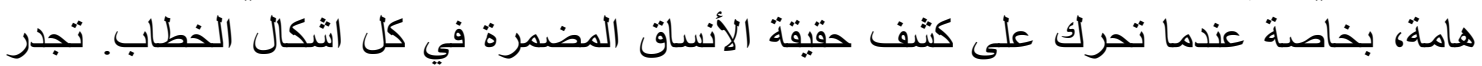
الإشارة إلى أن بوادر ممارسة النقد الثقافي قد ظهرت بادئ الأمر في أوربا نهاية القرن الثامن

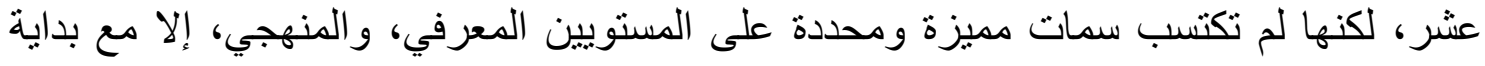

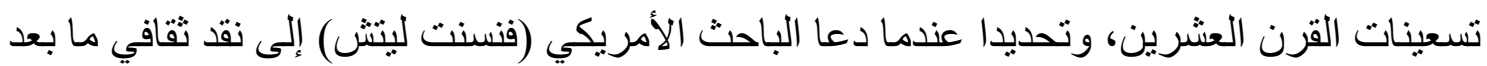

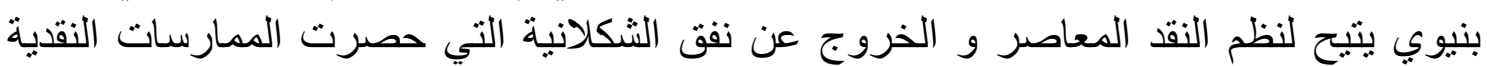
داخل إطار الأدب بالثكل الذي تفههة المؤسسات الأكاديمية الرسمية.

لقد شكل مصطلح النقد التقافي بوصفه فرع من فروع نقد النصوص العام، أهمية في قر اءة وتحليل

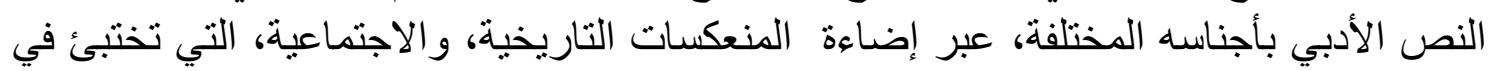

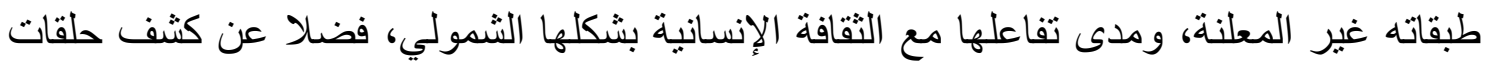
الارتباط والاتصال، بين البنية اللفظية، والمواقف الاجتماعية، و الفكرية، التي يتحقق من خلالها

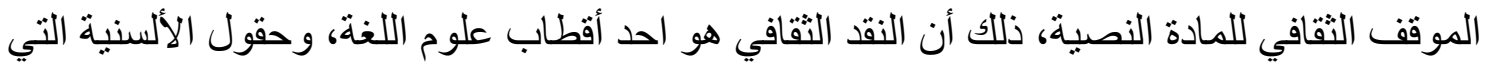
تعنى بتحليل الأنساق غير المصرح بها، التي ينطوي عليها الخطاب التقافي بتجلياته، و أنماطه،

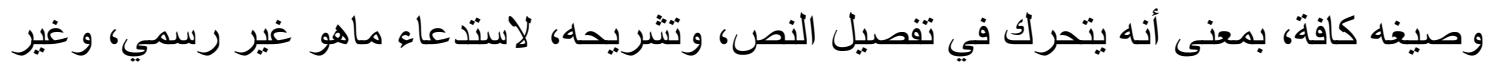

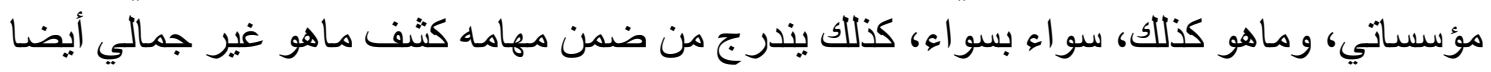

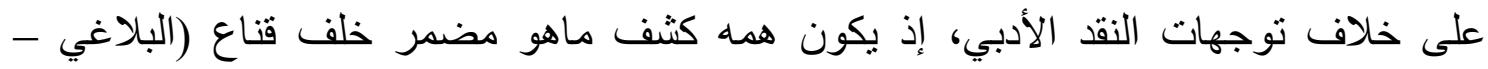

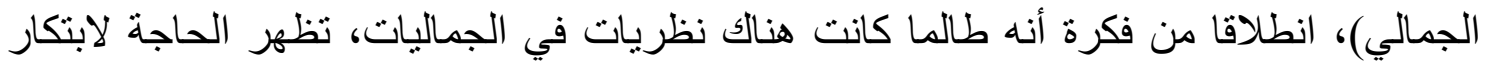

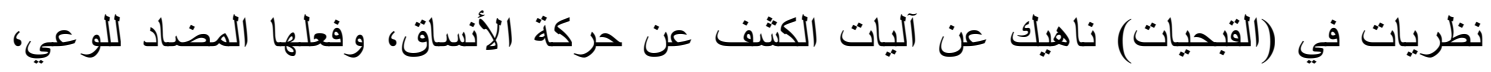
و الحس النقدي، لذلك تكمن جمالية النقد الثقافي في النص ذاته الذي يتمدد ليصبح بحجم ثقافة ما ليا

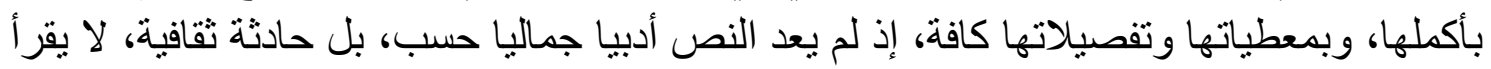

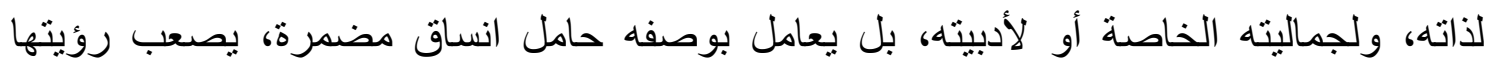
بو اسطة القراعة السطحية، وفي هذا الإطار تكون مهمة القارىء الناقد، هي الوقوف على الألى الأنساق 
المضمرة المرتبطة بدلالات مجازية كلية، وليس على نصوص ذات دلالات صريحة، إذ يمكن عده

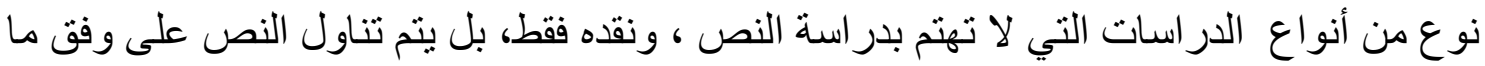

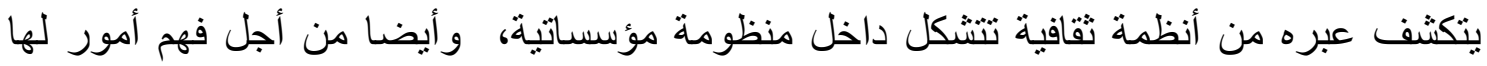

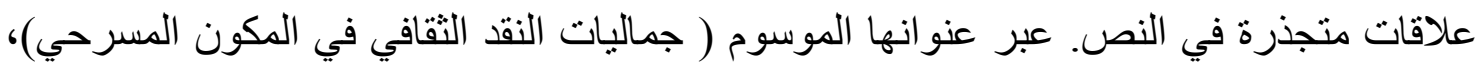
و على وفق ما حددته في تفصيلات البحث المنهجية التي جاءت بالثكل الآتي:

أو لا : الإطار المنهي : الذي تضمن مشكلة البحث و الحاجة إليه ، إذ شخصت الباحثة المشكلة التي

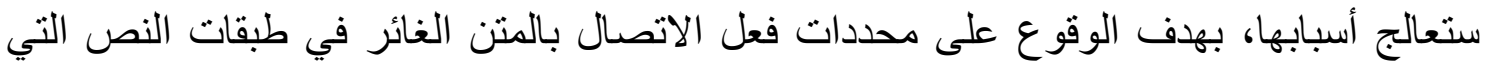

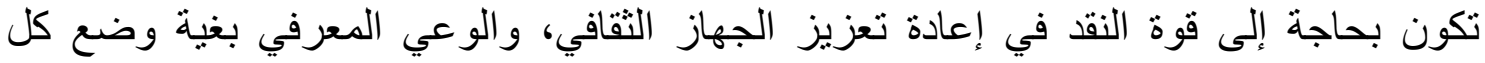
الجزئيات التي أغفلها النقد في بؤرة الرؤية، لتحقيق انتشار للمنظومات الفكرية عبر حقل التلقي

$$
\text { الايجابي للمكون المسرحي، }
$$

ثانيا الأطار النظري: ويتضمن المباحث الآتية: مشكلة البحث و الحاجة إلبه

لعبث ما بعد الحداثة دوراً مؤثرا و عميقا في التأثثر على الثقافة العالمية لما لها من دوراً كبيراً

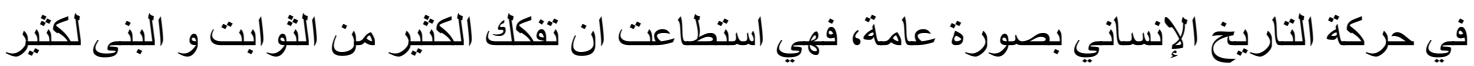

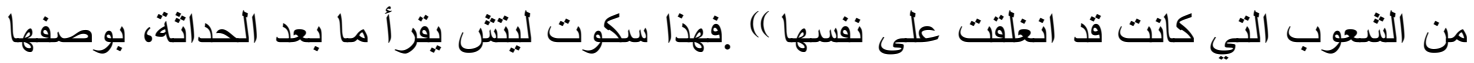
حدثا ثقافيا وتمنلك ثناثة مو اصفات عامة، فهي أولا إنتاج صيرورة التمايزات الثقافية، وهي ثنانيا

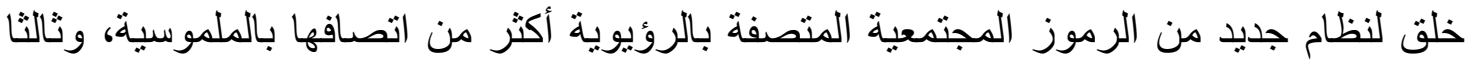

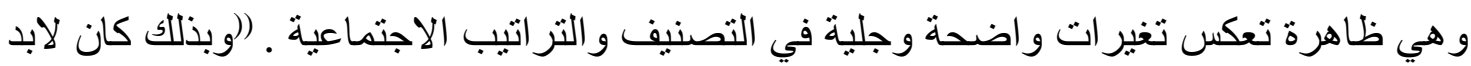
من الاهتمام بالوقوف بوجه التحديات الفكرية ـ التقافية .التي يحملها هذا المشروع للإنسانية جمعاء

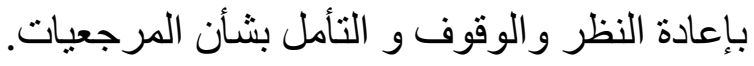

فالنقد الثقافي هو نوع من الدراسات التي لا تهتم بدراسة النص ونقده فقط، بل صار يأخذ

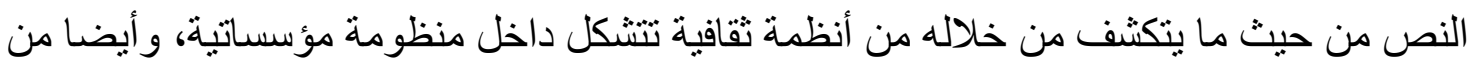

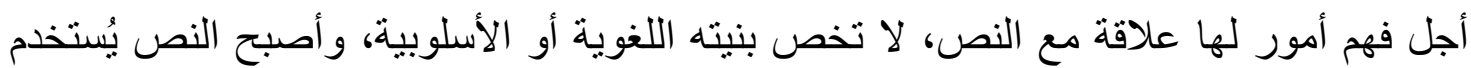

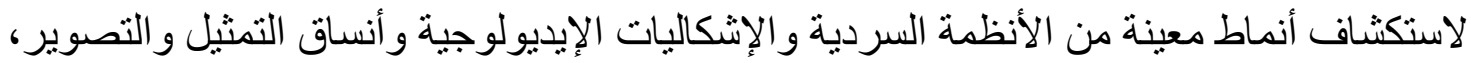

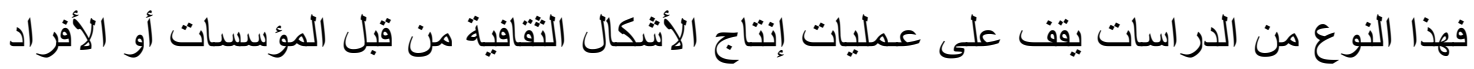

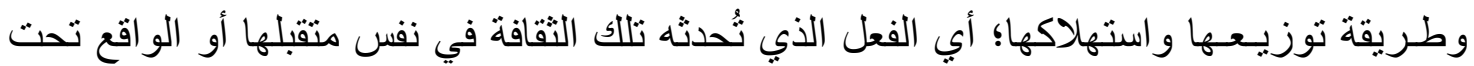

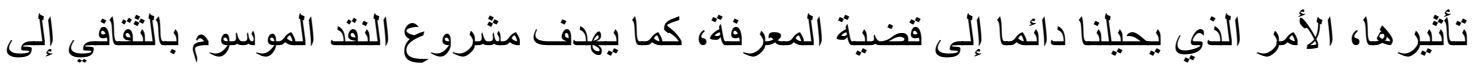
تحليل الثروط المتسبية في إنتاج مختلف أنماط مؤسسات السيطرة و التأثثر داخل ثقافة معينة من خلال تحديد وظيفة كل من القوى الاجتماعية و الاقتصادية و السياسية التي ثُنتج كل أشكال الظو اهر 
الثقافية، وقد أخذ ممثلو النقد التقافي على كواهلهم محاولة تعديل بنيات السلطة القائمة على تفضيل جنس بشري على آخر أو نمط فكري أو إيديولوجي على غيره مما حدا بالبعض إلى اعتبار هذا التها

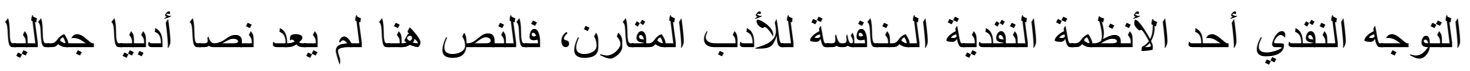

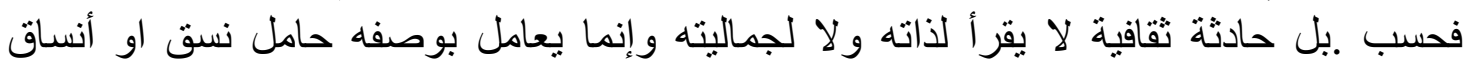

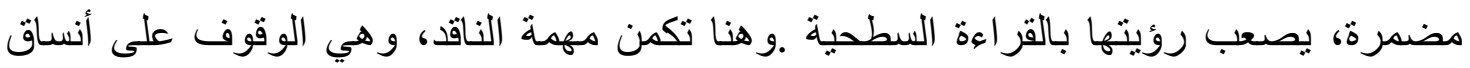

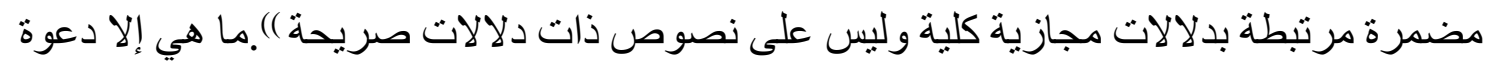
على الانفتاح على النصوص والكتابات التي همثت قصد إدماجها في المتن الثقافي وبغية كسر الحدود القومية و العرفية وتحقيق خطاب عالمي إنساني (و هذا ما دعى إليه دريدا في مناهضة

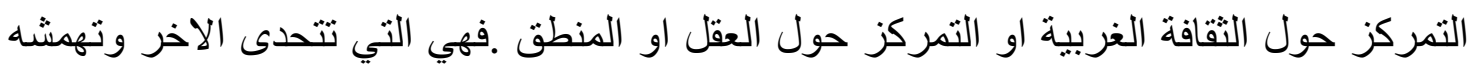
ولا تعترف به ، من هنا تحدث(( فنسنت ليتش عن النقد الثقافي بوصفه نقدا يتجاوز البنيوية وما

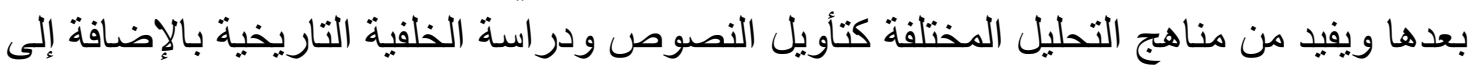
أفادته من الموقف الثقافي النقدي و التحليل المؤسساتي ) ).

اذا ما هو النقد الثقافي ؟ وكيف يكون الناقد الثقافي واعيا بقوة الثقافة، وكيف يمكن ان يبقى

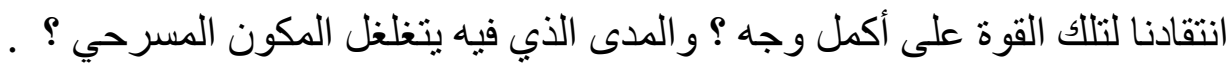

أهمية البحث تكمن أهمية البحث في انه يحاول أن يقر أ المكون الثقافي تبعا لمغايرة النص

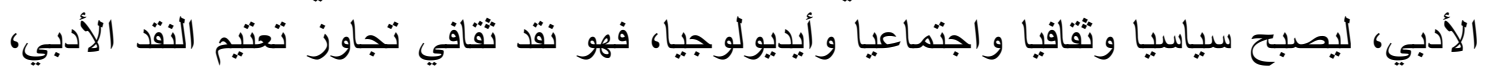

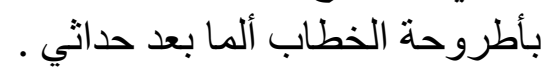
أهداف البحث

1- الكثف عن حركة التأثير الفعلية، هي للنص الجمالي المؤسساتي أم للنصوص الأخرى لا الا

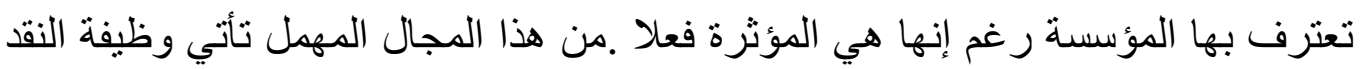

2- السعي إلى إعادة ترتيب الوعي و الدراية الذاتية المجتمعية .

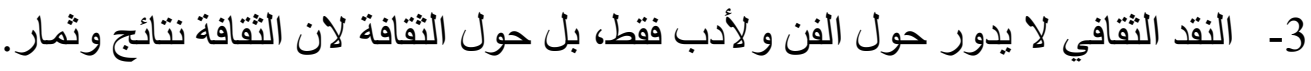

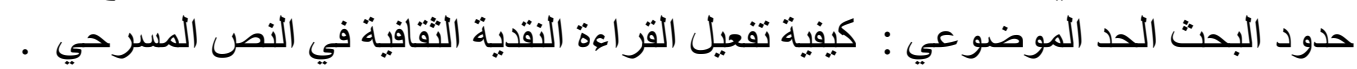

$$
\begin{aligned}
& \text { الحد المكانــــــ : النصوص الأدبية. } \\
& \text { الحد الزمانــــــ نمـاذج مختارة . } \\
& \text { تحديد المصطلحات / مصطلح النقد }
\end{aligned}
$$

الإطار النظري المبحث الأول مفهوم الثقافة. 
المبحث الثاني:

$$
\begin{aligned}
& \text { 1- المكون الثقافي اجتماعيا.. } \\
& \text { 2- المكون الثقافي إيديولوجيا. } \\
& \text { المبحث الثالث جماليات النقد الثقافي في المكون المسرحي الثولي } \\
& \text { ما اسفر عنه الإطار النظري من مؤشرات } \\
& \text { مصطلح النقد }
\end{aligned}
$$

صطلاحا في معجم المصطلحات الادبية المعاصرة تعرف على انها " كمدرسة ذوق عند الانظباعيين، او كنظرية للانتاج الادبي، عند ( ماثري)، اي فناو وعلما. ومن الملائم ان يصبح النقد

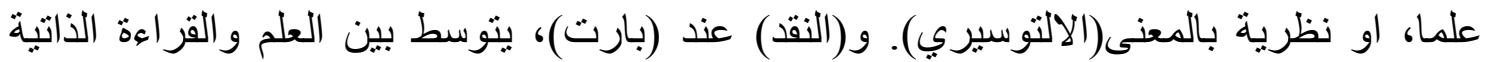

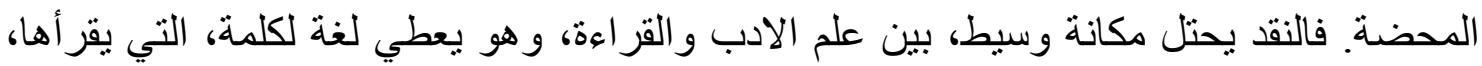

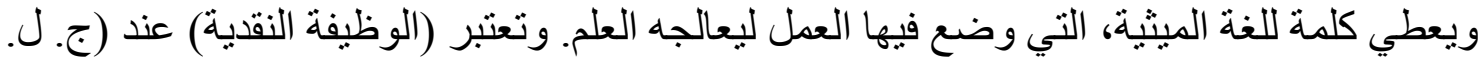
وري) عودة بالوعي،الى النظام الايديولوجي، الذي عليه ان ييقى بريئا، حتى يحقق عالميته. اما (جان ولهان)، فيرى في (النق) تاملات، يعلن استحقاق عمل ادبي، او عدم احقيته، في نيل الاعتبار

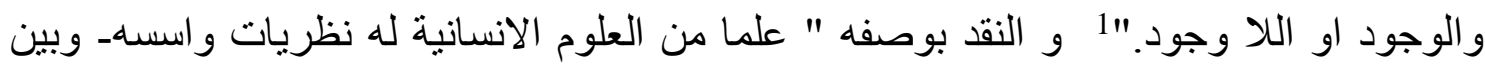
النقد من حيث التطبيق. فمن الواضح ان هذه النظريات و الاسس لا تتوحد مع النتاج الادبي بوصفيه

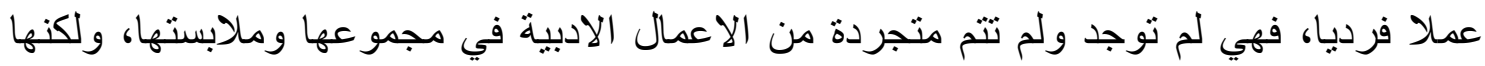
نتيجة لعمليات عقلية تركيبية مبدؤها النظر الدقيق و التامل العميق للنتاج الادبي"

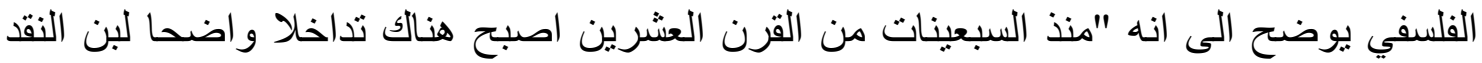

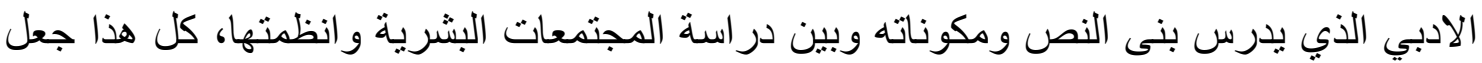
من مصطلح النظرية النقدي شائعا جدا في الاكاديميا لكنه مصطلح و اسع يغطي مجئ دجالا و واسعا من النظريات العلمية" من ملف

مفهوم الثقافة اصطلاحا الثقافة هي" علم انماط الكودات، التي تحدد عينة سوسير - ثقافية معينة.

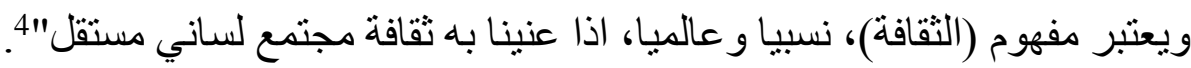

1 سعيد علوش: معجم المطلحات الادبية المعاصرة، منشورات المكتبة الجامعية، الدار البيضاء، 1984، ص124. 2 محمد غنيمي هلال: النقد ادبي الحديث، دار نهضة مصر ، القاهرة ، 1973، ص1. 3 مصطفى حسيبة: المعجم الفلسفي، دار اسامة للنشر والتوزيع، عمان- الاردن، 2012، ص625. 4 نفس المصدر: سعيد علوش، ص34. 
ترد كلمة (الثقافة) ومشتقاتها في اللغة العربية على معان عدة منها: الحذق و الفطنة، وسر عة أخذ

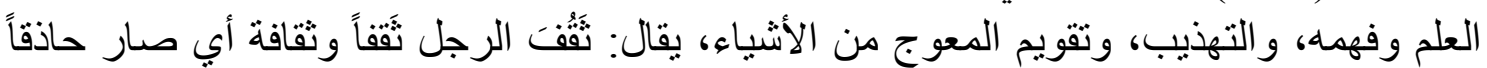

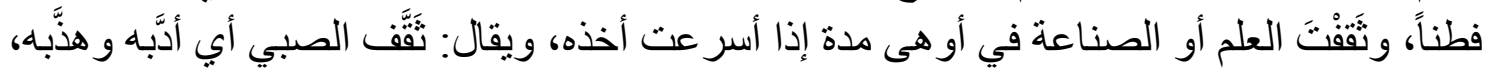

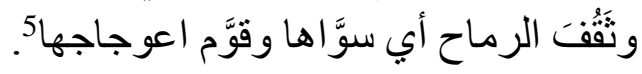

لقد تتو عت و اختلفت وتعددت تعريفات الثقافة بشكل اصبح من الغير الممكن حصر ها في تعريف معين. ولكن الباحثة قد ركزت في بحثها على اتجاهين في تللك التعريفات للتقافة والتي كانت

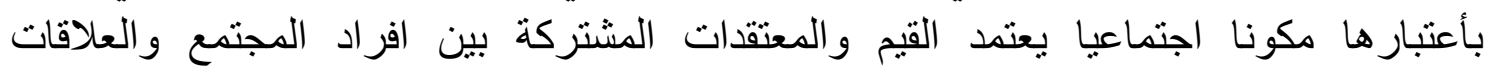

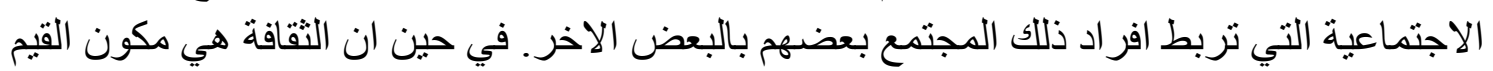

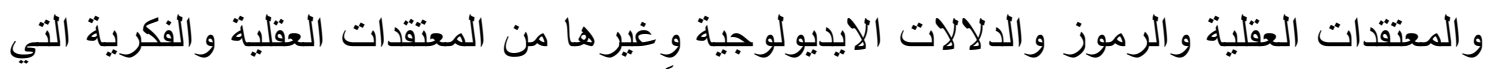

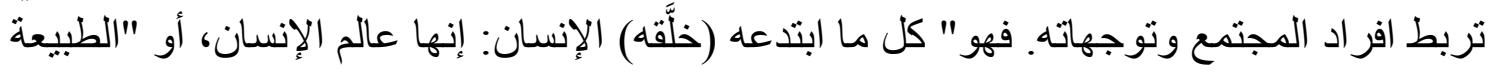

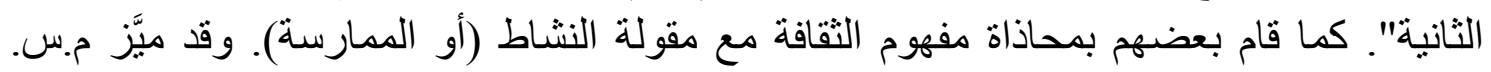

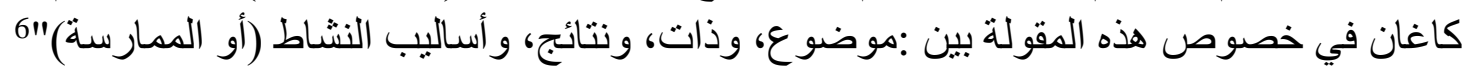
لا بنطبق مفهوم التقفة الا على ماهو انساني وضمن تنوع انماط حياة الانسان ومعتقداته. لقد تطور مفهوم الثقافة الاجتماعية وذلك بسبب الموضو عات التي ركزت بشكل خاص في طروحاتعا

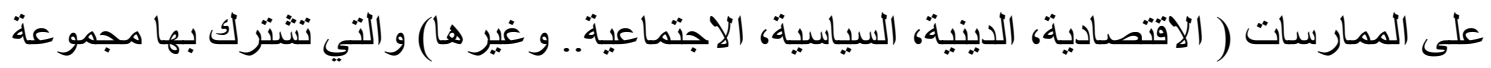

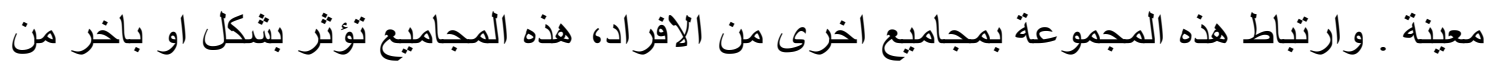

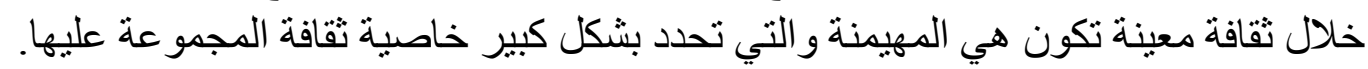
فالتقافة اذا هي " هذا الكل المركب الذي يشمل المعرفة و المعتقدات والفن والاخلاق والقانون

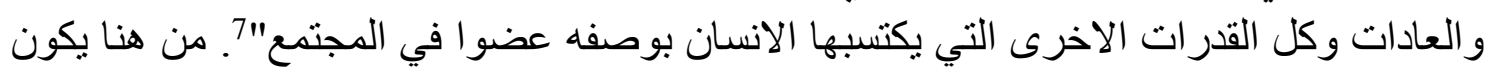

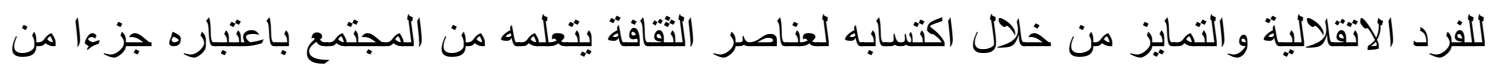

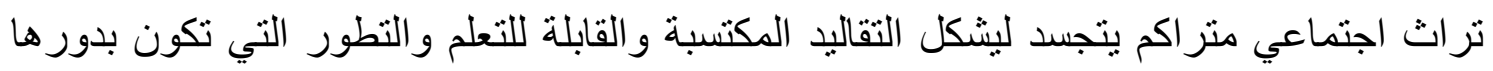
بعيدة كل البد عن الغر ائز وكل ناهو فطري، هي نتيجة الابتكار و الابداع الجماعي. ان الثقافة مفهوم

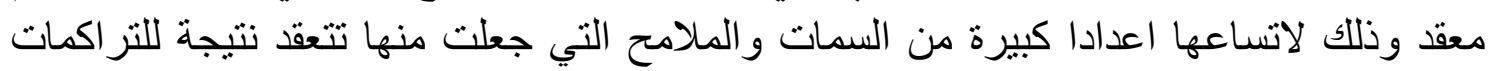

5 انظر : (اساس البلاغة ) للزمخشري، ومختار الصحاح) للرازي، و(لسان العرب) لابن منظور.

6 كاغان: النشاط الثشري، موسكو، 1974.

7دنيس كوش:مفهوم الثقافة في الغلوم الاجتماعية، تر:منير السعيداني، مركز دراسات الوحدة العربية، المنظمة العربية للترجمة، ط1، بيروت، 2007، ص31. 
الاجتماعية والتراثية لصور منوالية هذا خلق صعوبة كبيرة امام الباحثين لايجاد تعرف محدد للثقافة.

\section{المبحث الثانسي المكون الثقافي اجتماعيا}

يعتبر هذا المكون اسلوب من اساليب السلوك المشتقة من مجالات النشاط البشري اليومي، متأثر ا تأثثر ا مباشر ا بكل مايدور حوله من وقائع سواء كانت اقتصادية ، سياسية، دينية ، تاريخية ،

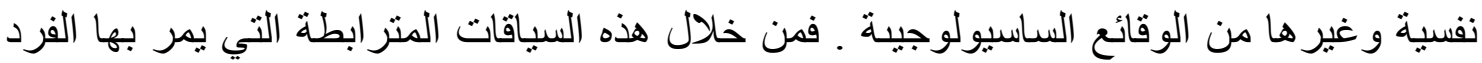

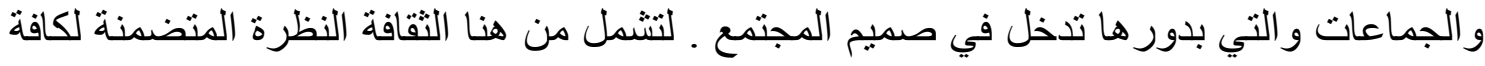

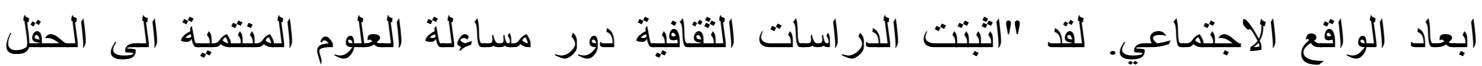
الاجتماعي وعلوم الانسان، واستجوبت ممارسات النقد الادبي التقليدية وممارسات النظرية الجمالية"8 لتكون بدور ها قادرة على ان تضع الفرد في السياق الاوسع للمجتمع بالثكل الثمولي ولئي و الذي ممكن ان يتسع كل الاتجاهات و الزوايا التفكير السسيولوجي الذي لئي يعتمد على النى جانبين مهمين

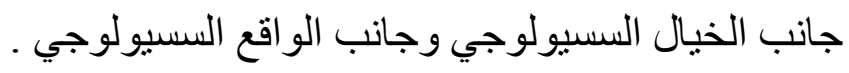

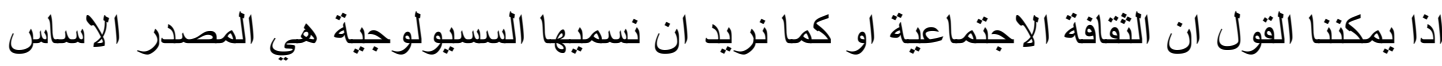

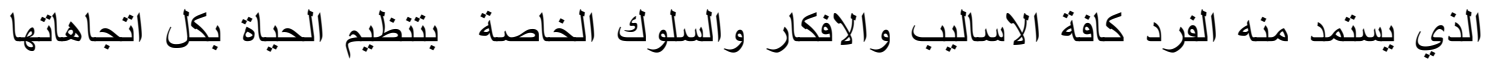
الانفعالية و العاطفية.. و غير ها. و التي يشترك فيها افر اد المجتمع عادة من خلال علاقاتهم وتو اصلهم الحياتي اليومي. لذا الثقافة يمكن ان تكون ذلك المزيج المتنوع و المختلف لكل ما نفكر ونتنسارك به به واله

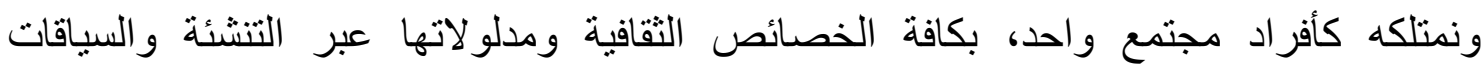
الاجتماعية التي تدخل في تنمية افكار ابناء المجتمع الواحد. اذا نتوصل من ذللك ان التقافة هي ودي

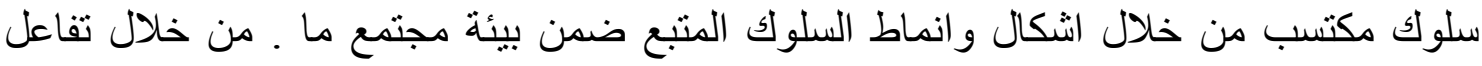

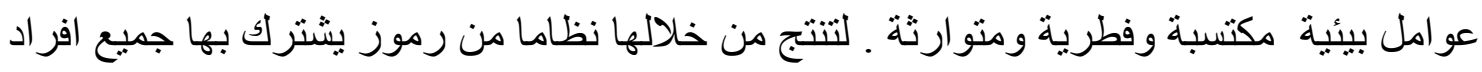

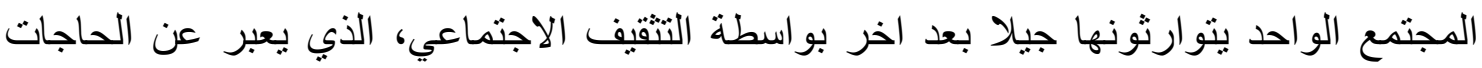
الضرورية للفرد.فالثقافة هي" نظام دلالي يفضي حتما بالنظام الاجتماعي المعين الى حتمية التبادل

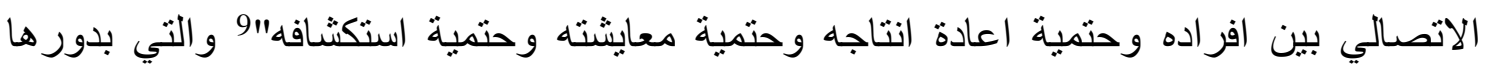

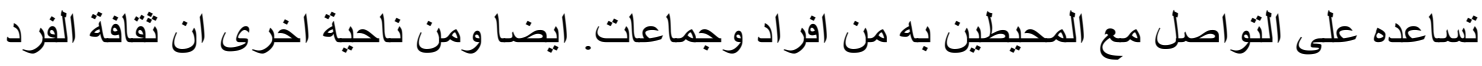
منفردا بذاته هذه الثقافة المترسبة عند الفرد نتيجة نتاج جماعي مكتسب من الاخر واعن والمحيطه الاجتماعي و هناك ثقافة ايضا متوارثة محصورة ضمن بيئة معينة هذه تكون امتدادا لمستويات عدة

8 8 ميجان الرويلي و سعد الباز عي: دليل الناقد الادبي، المركز الثقافي العربي، الدار البيضاء، ط2، 2000، ص73.

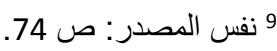


من الاليات المكونة لثقافة الفرد الواحد والتي من خلالها يمكنه ان ينتج ويبدع ضمن مجال الفن

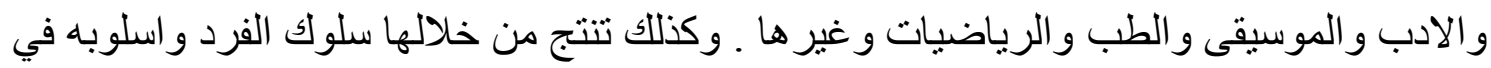

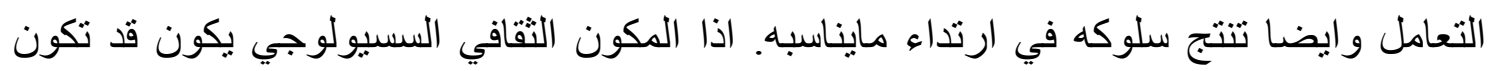

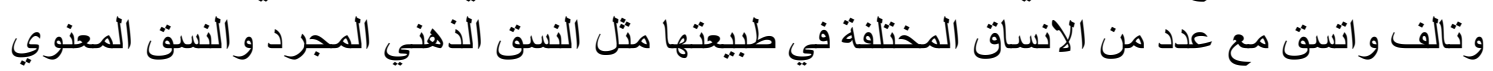

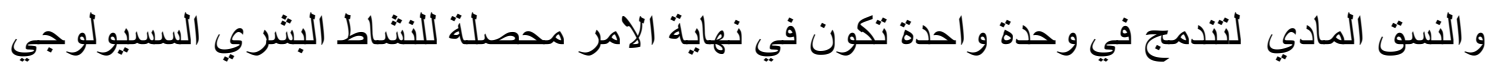
ضمن مجتمع متكامل يكون بدوره ثقافة خاصة به يتميز وينفرد بها في عن باقي التي الثقافات الاخرى.

\section{المكون الثقافي ابإيولوجيا}

يهتم النقد الثقافي باكتشاف الانساق الثقافية المضمرة ودر استها في سياقها التقافي الايديولوجي الذي تولد من خلال المنظور الفكري سياسيا و اقتصاديا وطبقيا ، ضمن المجتمع نتيجة تر اكمات ثقافية

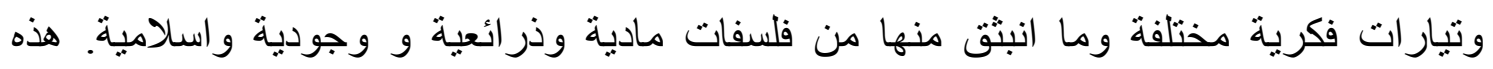

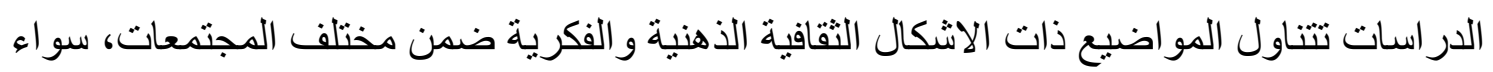

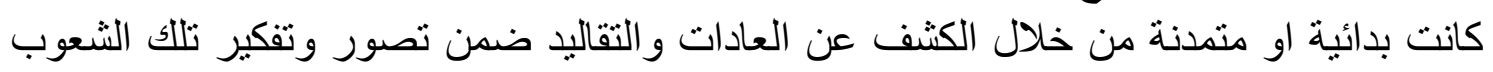
يعتمد مدى و عي الافر اد يما يقدمونه من دعم نمط حياتهم على مستوى الوعي الثقافي لديهم" 10 اذاذ هذه الدر اسات الثقافية تكثف عن الافكار التي ترتبط بعالم الخيال والفن من خلال التفكير الدلالي دئي

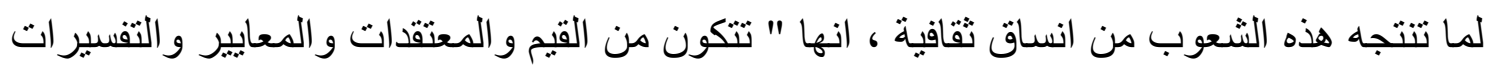

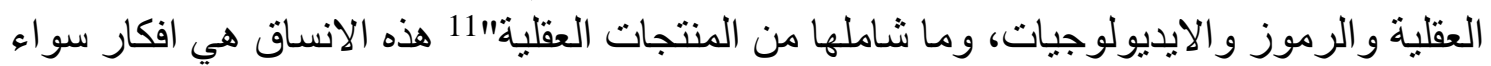

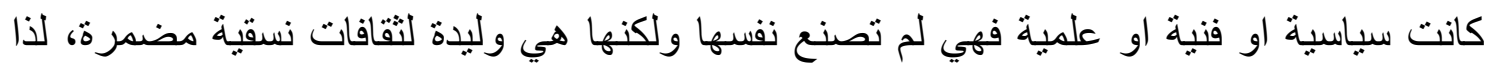
يكون تقييمنا وطرق تفكيرنا وفهنا في تفسير النصوص هي نتيجة سياقات نسقية مضمرة للمؤسسة

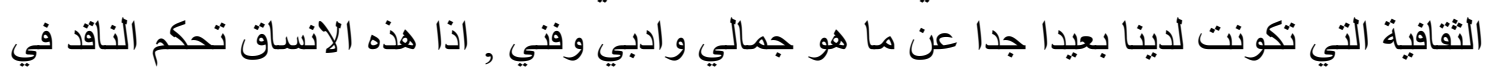

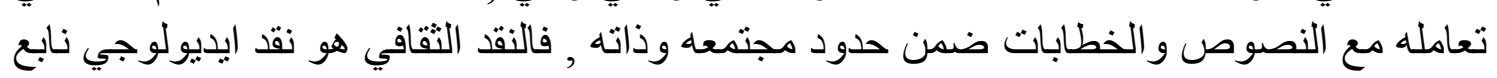

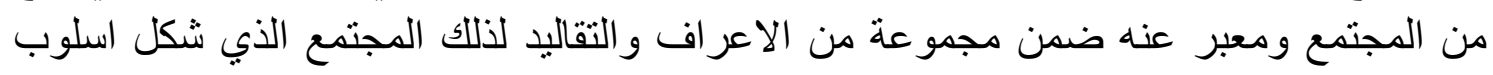

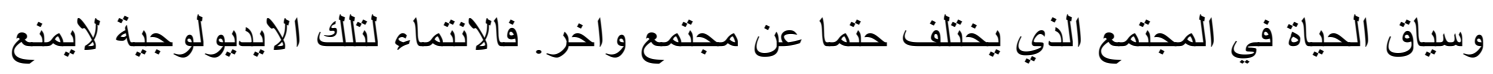
بالضرورة عدم احترام الايديوبوجيات الاخرى او الاساءة لها فلكل مجتمع سياستة وتفكيره

10 مجمو عة من الكتاب: نظرية الثقافة، تر: علي سيد الصاوي، عالم المعرفة، (223) المجلس الوطني للثقافة والفنون والاداب، الكويت، 1997، ص51.

11 مجمو عة من الكتاب: نظرية الثقافة، تر: علي سيد الصاوي، عالم المعرفة، (223) المجلس الوطني للثقافة والفنون والاداب، الككيت، 
و اعتقاده و هذا لايشكل او يخلق صر اع مع المجتمعات الاخرى بل على العكس هي ثقافة الاختلاف

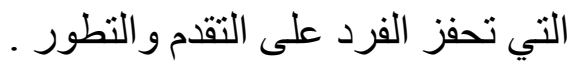

\section{المبحث الرابع جماليات النقد الثقافي في المكون المسرحي}

لعبت ما بعد الحداثة دوراً مؤثرا و عميقا في التأثير على التقافة العالمية لما لها من دور أ كبيراً في حركة التاريخ الإنساني بصورة عامة، فهي استطاعت ان تفكلك الكثير من الثوابت و البنى لكثير

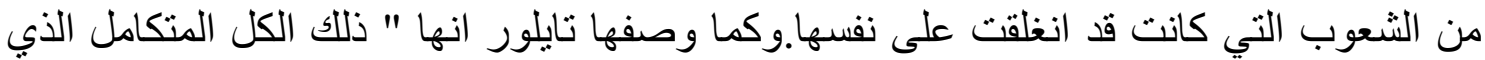
يشمل المعرفة، و المعتقدات، و الفنون، والأخلاقيات، والقوانين، والأعر اف، و و القدرات الأخرى، أنهات

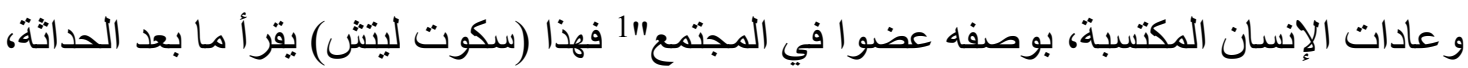

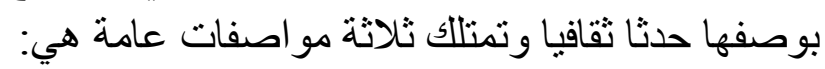
أو لا: إنتاج صيرورة التمايزات الثقافية.

ثانيا: خلق لنظام جديد من الرموز المجتمعية المتصفة بالرؤيوية أكثر من اتصافها بالملموسية، ثالثا:هي ظاهرة تعكس تغير ات و اضحة وجلية في التصنيف و التر اتيب الاجتماعية. فهي بو اعث سيكولوجية وسياسية لتطال الحياة الفنيةـ المسرحية في بسط قر اعة ثانية للثقافة عبر

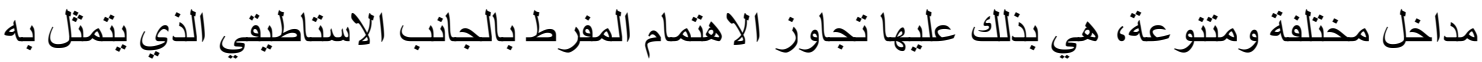

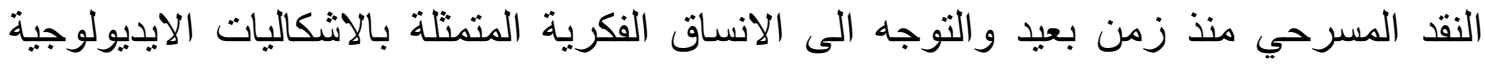

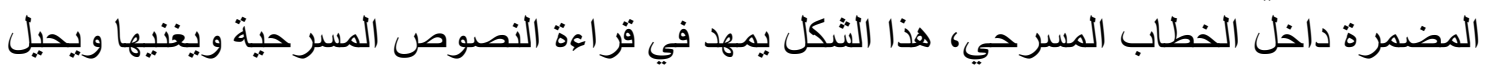

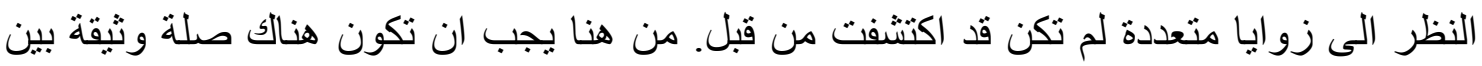
النصوص والعلاقات المكانية والزمانية وتطورها في شبكة العلاقات الاجتماعية والسياسية

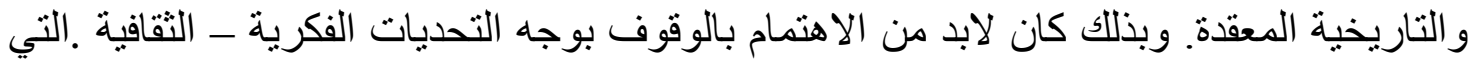

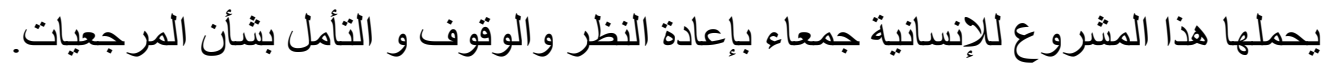

فالنقد الثقافي هو نوع من الدراسات التي لا تهتم بدراسة النص ونقده فقط، بل صار يأخذ

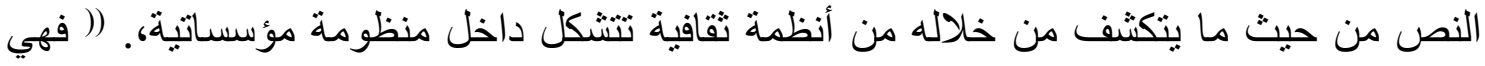

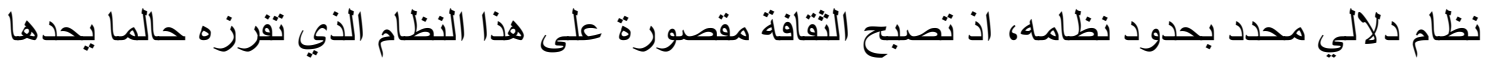

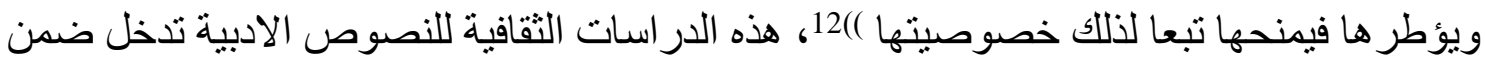

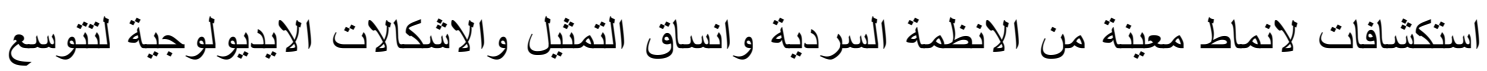

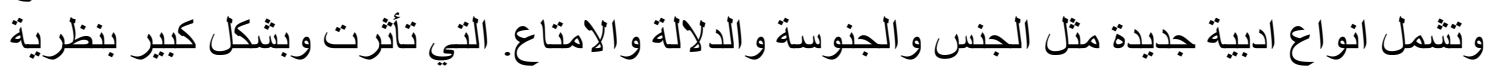


غر امشي بتوظيفها لمفهوم المهيمنة اذ تعتبر الدراسات الثقافية عبارة عن مجموعة من العلاقات

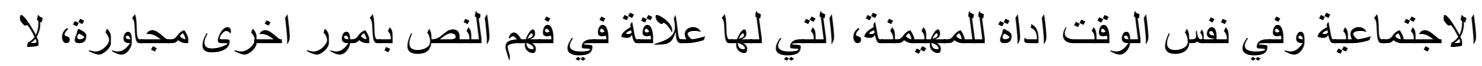

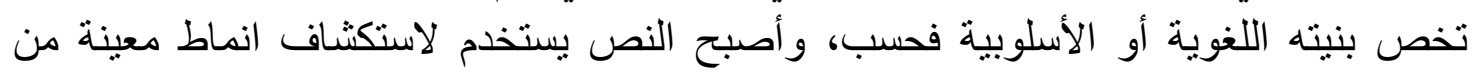

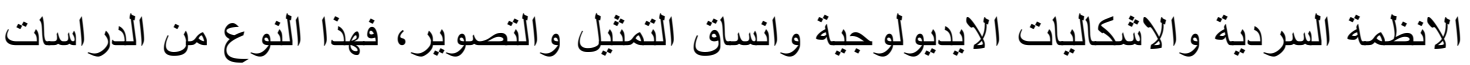

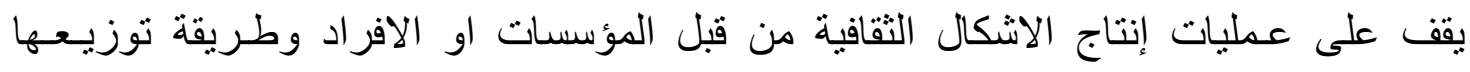

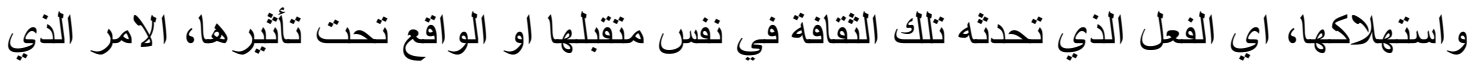

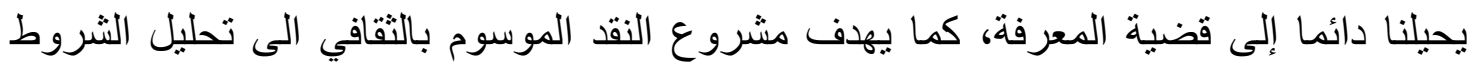

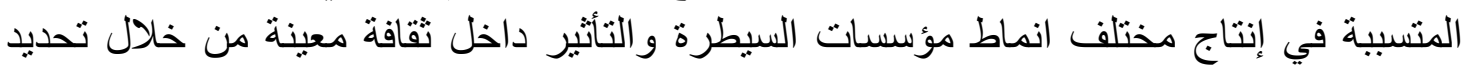
وظيفة كل من القوى الاجتماعية والاقتصادية والسياسية التي تنتج كل اشكال الظواهر التر الثقافية فهو

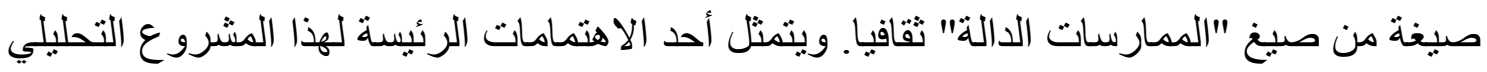

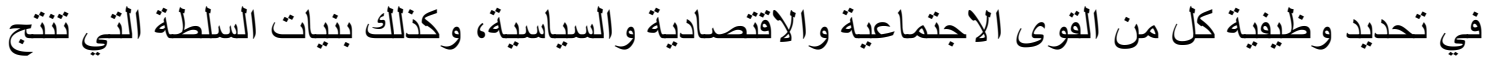

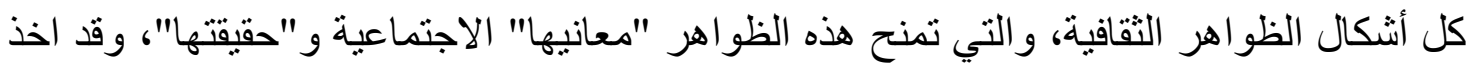

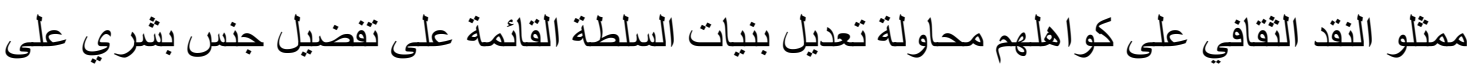

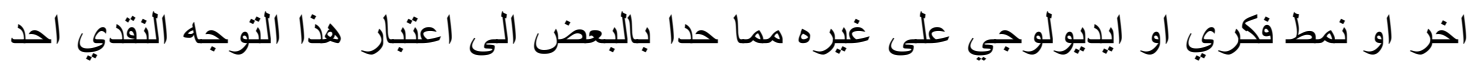

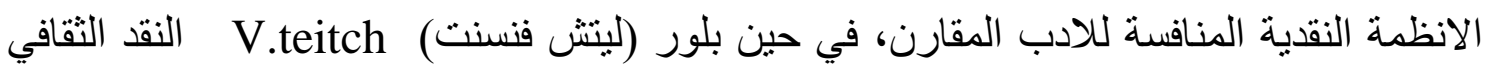

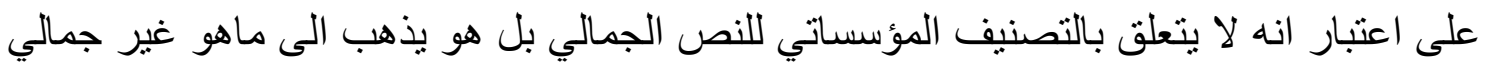

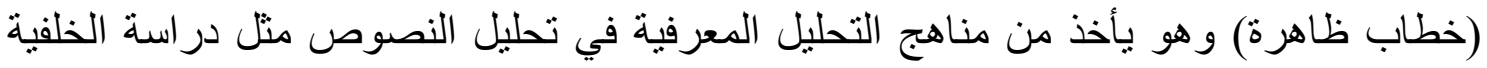
التاريخية والتحليل المؤسساتي، ويؤكد ليتش على ان النقد الند الثقافي يركز على انظمة الخطاب كما

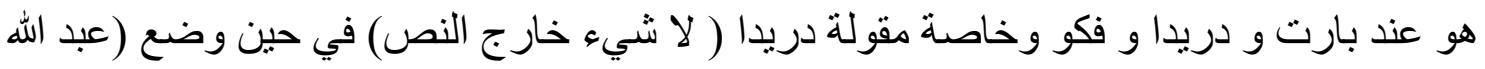
الغذامي) النقد الثقافي بانه فرع من فروع نقد النصوص العام فهو بذللك احد علوم اللغة وحقول

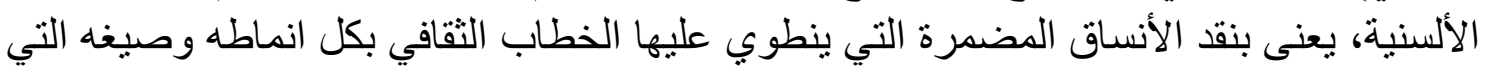

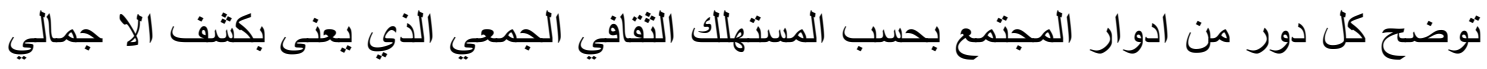

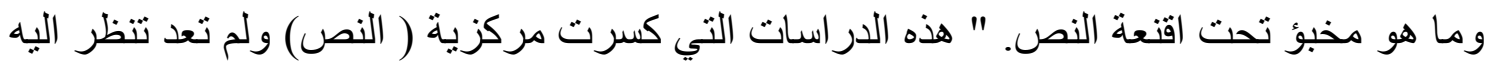

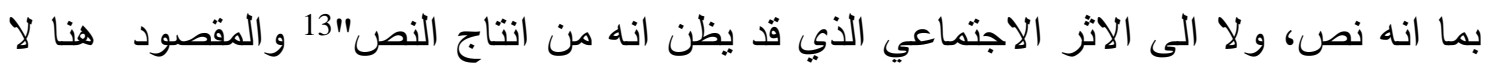

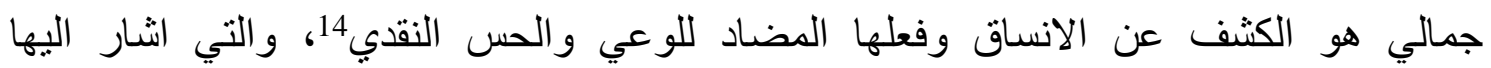
(جاكوبسن) في نظريته (التواصلية) المرنكزة على ست عناصر اساسية: المرسل، المرسل اليه،

13 عبد الله الغذامي: النق الثقافي قراءة في الانساق الثقافية العربية،المركز الثقافي العربي، ط3، اللملكة المغربية، لبنان- بيروت،ط3،

$$
\text { .17. 2005 ص. }
$$

14 زيودين ساردار و بورين فان لون: الدراسات الثقافية و مفهوم الثقافة في العلوم الاجتماعية، تر :وفاء عبد القادر، المجلس الأعلى 
الرسالة، السياق، الثفرة، الاتصال. التي تقابلها ست وظائف: النفعية، التعبيرية، المرجعية، المعجمية، التببيهية، الثاعرية (الجمالية). ليثناركه الغذامي باضافة وظيفة سادسة هي النسقية، الى لى جانب عنصر جديد هو عنصر النسق موضحا في المخطط التالي:

الشفرة_السياق__الرسالة المرسل ـالمرسل اليه ــ أداة الاتصال ـ العنصر النسقي فالنص هنا لم يعد نصا أدبيا جماليا فحسب .بل حادثة ثقافية لا يقر أ لذاته و لا لجماليته و إنما يعامل

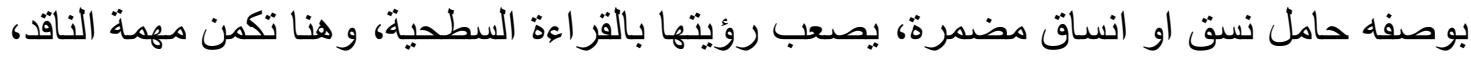
في الوقوف على انساق مضمرة مرتبطة بدلالات مجازية كلية وليس على نصوص ذاعة ذات دلالات

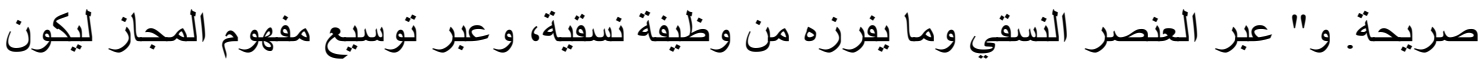

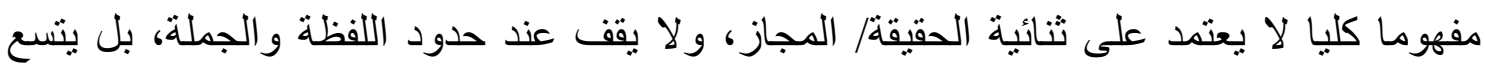

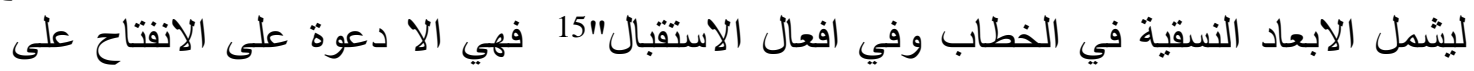
النصوص والكتابات التي همشت قصد إدماجها في المنن الثقافي وبغية كسر الحدود القومية و العرفية وتحقيق خطاب عالمي إنساني. وهذا ما دعى إليه دريدا في مناهضة التمركز حول الثقافة ولئة

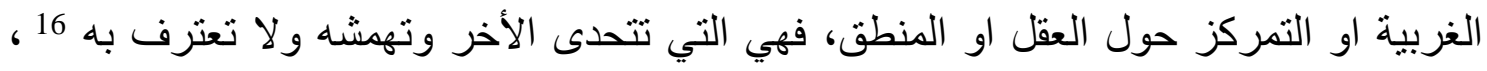

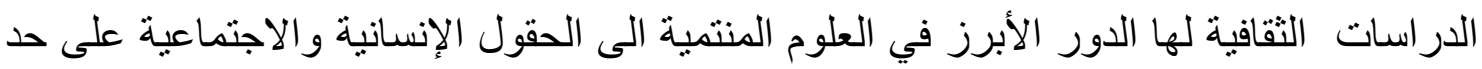

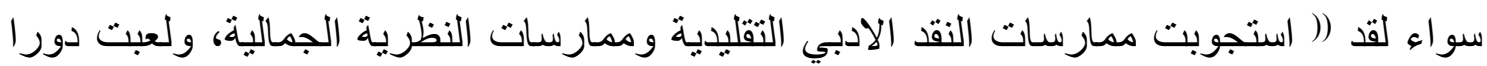

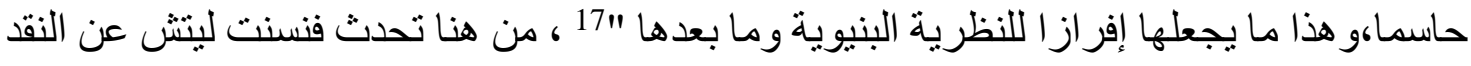

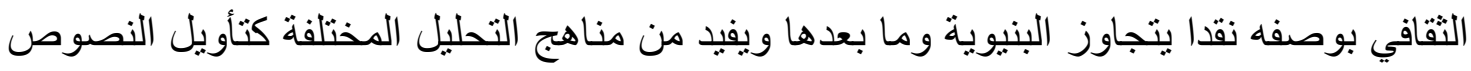

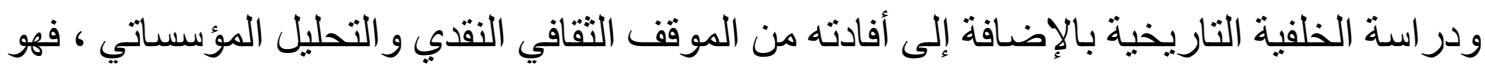

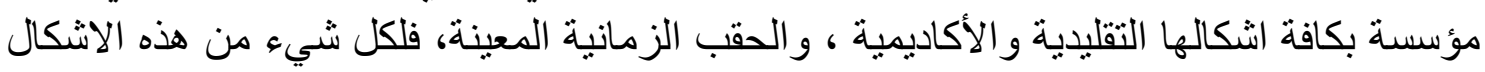

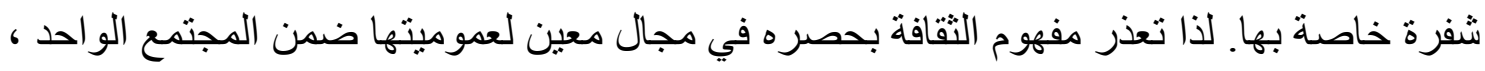

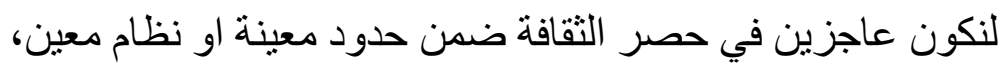

النقد القافي هو صورة جديدة في ربط النص بمحيطه الثقافي، فهو يمكن ان بتغير بتغير الناقد

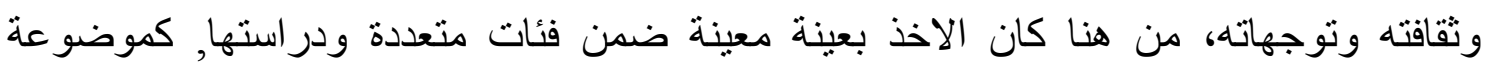

15 عبد الله محمد الغذامي: النقد الثقافي (قراءة في الأنساق الثقافية العربية)، المركز الثقافي العربي، بالدار البيضاء وبيروت، ط 3 3، 2005.

16 ينظر : عبد الله محمد الغذامي: النقد الثقافي (قراءة في الأنساق الثقافية العربية)، المركز الثقافي العربي، بالدار البيضاء وبيروت، ط 3، 2001. 
الجنوسة او على الدر اسات النسائية و غير ها من الدر اسات التي تخصص مجتمعات وفئات كبيرة.

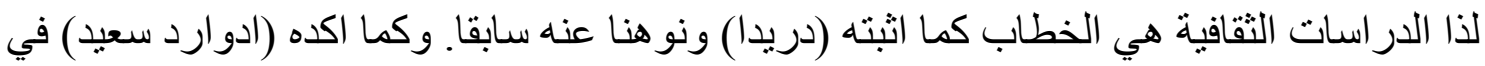

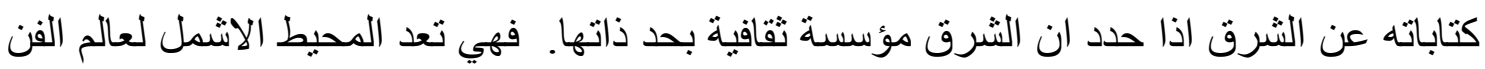

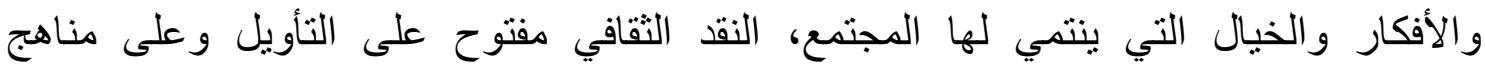
السيميائيات وتحليل الخطاب ومختلف العلوم الإنسانية المحيطة بالآداب، فو يسعى الى لى تطوير

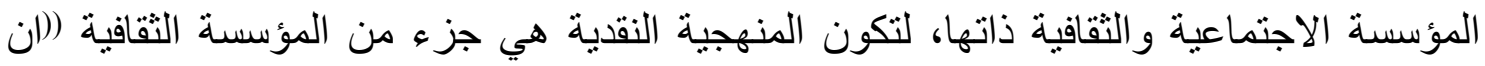

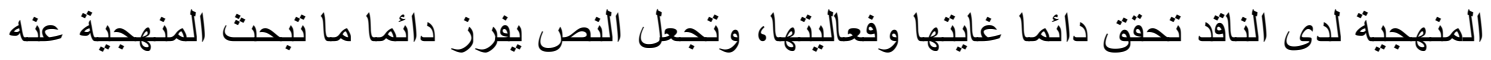

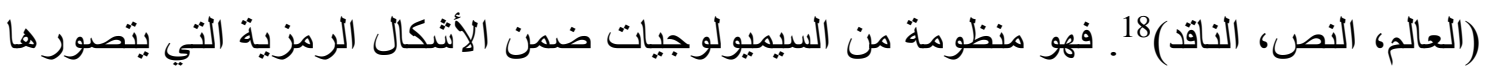

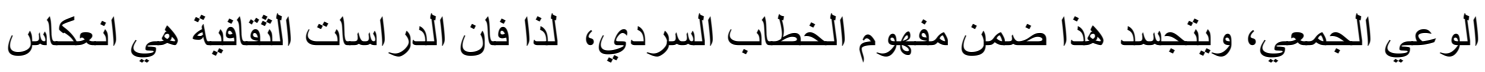

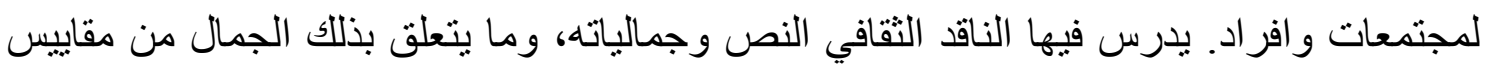
اومؤثرات او متغير ات، هي محاولة للبحث عن الانساق الثقافية في النص، " التي يمكن من خلالها

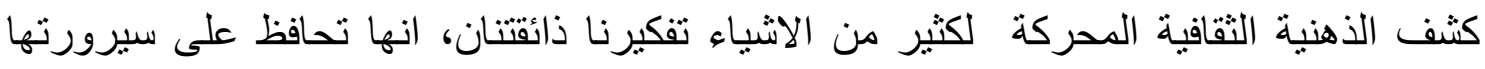

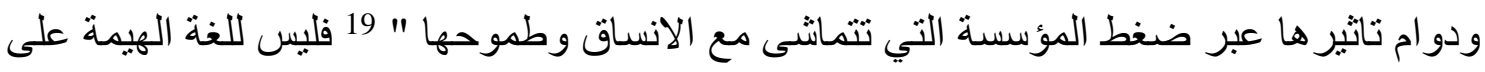

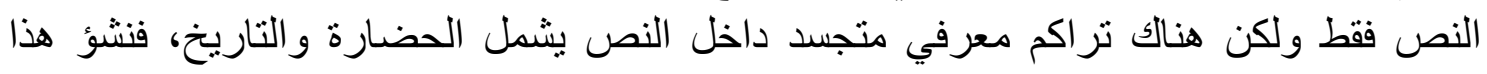
التر ابط بين النقد الثقافي و المجتمع و الحضارة هو ما يمكن ان يصنع اعمالا ادبية عظيمة.

$$
\text { تحليل مسرحية واقع خر افي / للكاتب عبد النبي الزيدي } 20
$$

يحمل النص من خلال عنوانه ( واقع خر افي) على دلالات ثقافية رمزية، تمثلت ضمن حوارية اسطورية وحوارية واقية سردية انتشلها الكاتب من صميم الواقع المعاش. مستعير ها من خلال

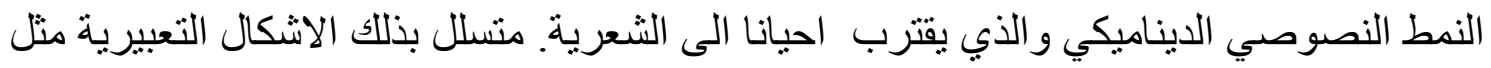

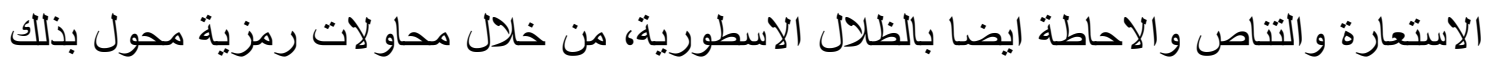

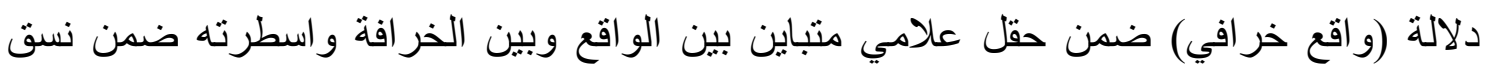

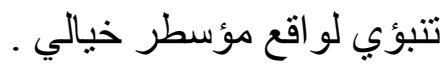

ان الكاتب (الزيدي) لم يختر عنو انه اعتباطيا بل كان اختياره مقصودا عبر مرجع مؤثر في الذات

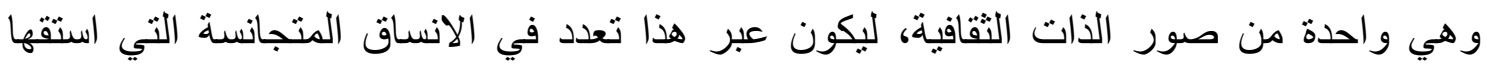

$$
18 \text { دليل الناقد الادبي: مصدر سابق، ص77. }
$$

19 عبد الرحمن عبد اللة: النقد الثقافي في الخطاب النقدي العربي العراق اموذجا، ط1، وزارة الثقافة" اصدارات مشروع بغداد عاصمة

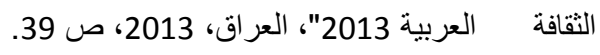
20 عبد النبي الزيدي: مسرحية واقع خر افي، مخطوط غير منشور، 2014. 
الكاتب من عروق ثقافته. و وبذلك تكون قد تشكلت ضمن سياق نصي منكامل ضمن بنية در امية لا تعتمد على كونه كاتبا ادبيا وحسب وفئ ولكن بكونه كاتبا ثقافيا . ان التعامل مع مفردة الموت التي كانت هي المحور الاساسي للنص بعتبار ها مدلو لا انطلوجيا ثقافيا

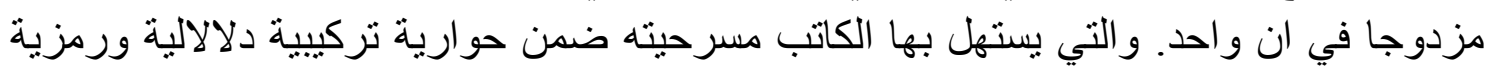
و اقعية اسطورية كما في الحوار الاتي ولئ صاحب القبر : جأتك ايها الميت برجاء خاص. الميت: ماذا يمكن ان افعل للك ايها الحي والهارب من الحرب؟ لاتقل لي اريد الاختباء معك في القير . كما نرى بالكاد يستو عب جثتي.

نلاحظ ان علامات الاسناد تدور في فضاء تشخيصي تجسيدي ولكنها مختارة بدقة لتعبر عن الدلالة العدمية، فالميت لا يمكن ان بحقق املا للاحياء ، ليكون بذلك الكاتب قد رحل صور ا جديدة متخيلة

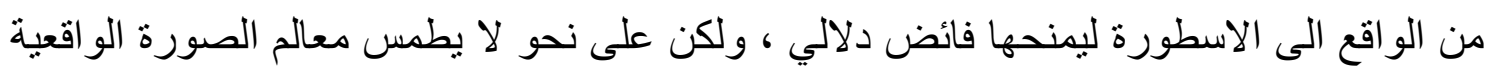

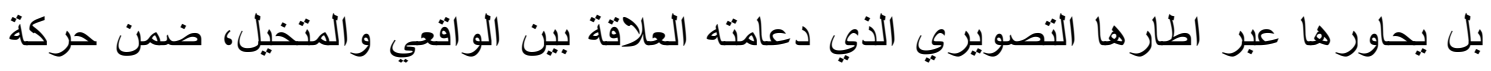

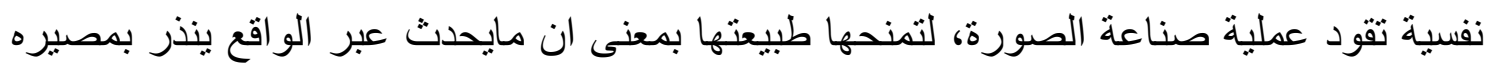

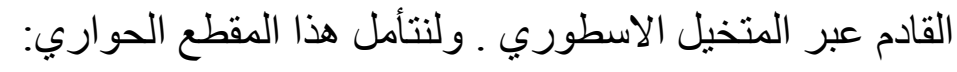
الميت: هم وضعوني في هذه الحفرة ... ما شأني؟ صاحب القبر : وهذا هو الاحتلال. الميت: الاحتلال ايضا ؟! صاحب القبر : اذا لم تخرج... انا مضطر لاستخدام العنف معك. الميت: و انا سأدافع عن قبري حتى اخر لحظة من جثتي.

حين نتأمل ملامح هذا الحوار نجد انه تشكل وفق ثقافة مجتمع، فقد نقل لنا الكاتب المستشرف من

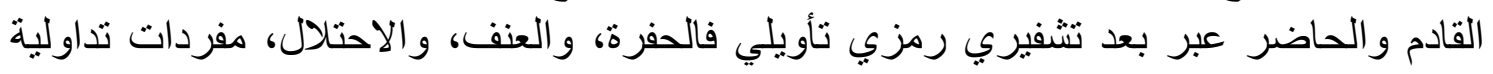

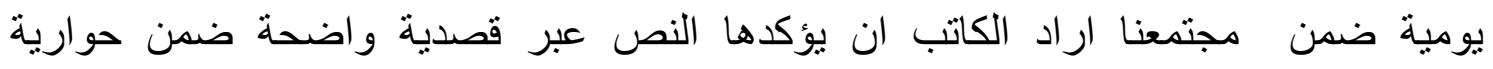
متصاعدة, لنتامل كذلك هذا المقطع الذي يبين تصاعد في الحدث الثين الدر امي: الميت: دعني اعيش في وطني. صاحب القبر : وطنلك ؟ ماذا تعني؟ 


$$
\text { الميت: القبر .. احلى وطن ! كل شيء ابيض هذا رغم السواد. }
$$

صاحب القبر : (يصر خ به) انا اتحدث مع ميت لايفهم لغة الاحياء... سأموت ايها الرجل عن قريب، واريد ان ادفن في هذا القبر الذي اشتريت ارضه بأمو الي. انت متجاوز

$$
\text { على ملكين لا يصح ان ينام الموتى في قبر حو اسم ! }
$$

يشير هذا الحوار ضمن منضومة ثقافية اجتماعية متفجرة ضمن صر اع بين الالفة و العصيان كرد

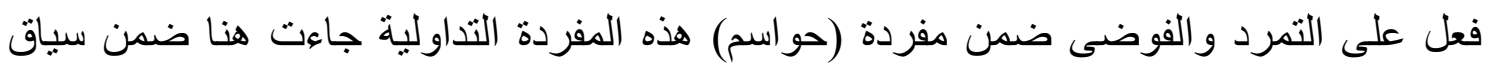

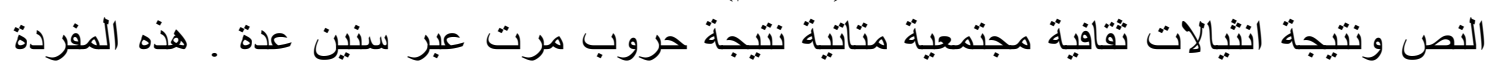

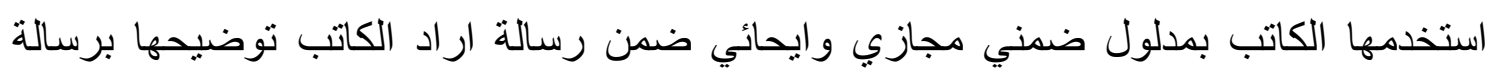

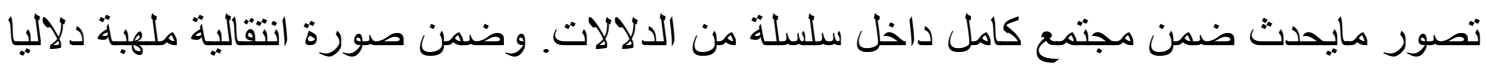

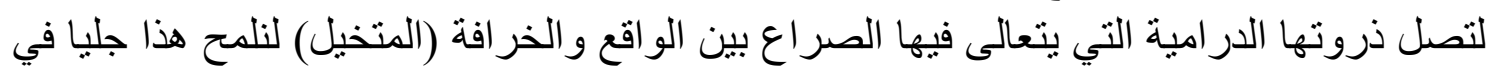
تشخيصات ار ادها الكاتب ليدلل بها ضمن علامات كنائية عن الموت العاصف الذي الذي يؤطر الحئ الحياة اليومية عبر قراعة لثقافة البعد الههجي لما يحدث في المجتمع. ضمن نوالد انساق ثقافية طارئة اقتحمت البنية الاجتماعية باطر واشكال مختلفة من عنف وحرب وارهاب هاب وتفجير ات غير منتهية

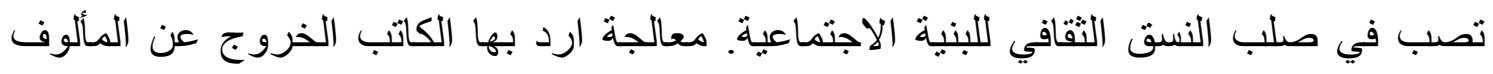

$$
\text { ضن ون واقع خر افي }
$$

المصادر

1- ميجان الرويلي و سعد اليازعي: دليل الناقد الادبي، المركز الثقافي العربي، ط2، الدار

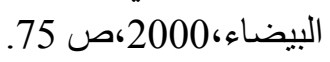

2- زيودين ساردار و بورين فان لون: الدراسات الثقافية و مفهوم الثقافة في العلوم الاجتماعية، تر :وفاء عبد

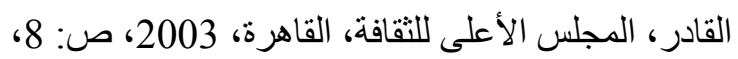

3- ينظر : عبد الله محمد الغذامي: النقد الثقافي (قراءة في الأنساق الثقافية العربية)، المركز الثقافي العربي،

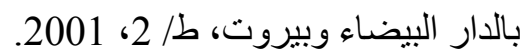

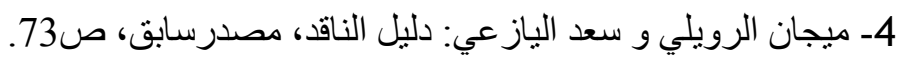

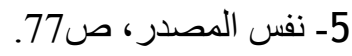

6- مصطفى حسيبة: المعجم الفلسفي، دار اسامة للنشر والتوزيع، عمان- الاردن،

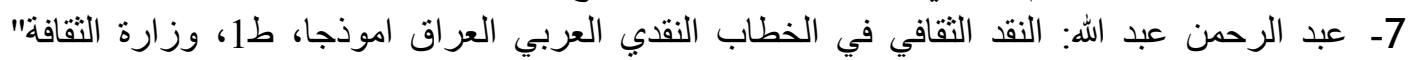

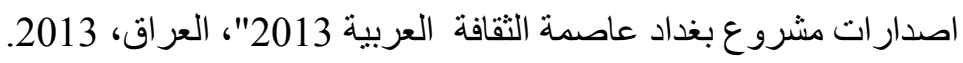
8- عبد النبي الزيدي: مسرحية واقع خر افي، مخطوط غير منشور، 2014. 